\title{
Notes on the occurrence of Gampsocoris Fuss, 1852 (Hemiptera: Heteroptera: Berytidae) in Poland
}

\author{
Artur TASZAKOWSKI \\ Department of Zoology, Faculty of Biology and Environmental Protection, University of Silesia, Bankowa 9, 40-007 \\ Katowice, Poland; ataszakowski@us.edu.pl
}

\begin{abstract}
In Poland the genus Gampsocoris Fuss, 1852 is represented by two species: G. punctipes (Germar, 1822) and G. culicinus Seidenstücker, 1948. The paper presents new localities of both species, including the second record of G. culicinus in Poland. Additional information on their biology is provided. A possible immigration route of G. culicinus into Polish territory is discussed.
\end{abstract}

Key words: hemipterans, Gampsocoris punctipes, Gampsocoris culicinus, new records, distribution, the Beskid Mountains

\section{INTRODUCTION}

The genus Gampsocoris Fuss, 1852 belongs to the family Berytidae Fieber, 1851 and the subfamily Gampsocorinae Southwood \& Leston, 1959. Seventeen species of this genus are known worldwide according to Wahmann et al. (2007) while Henry \& Froeschner (1998) give the number of '18 species worldwide. Nine of them occur in the Palearctic region (Péricart 2001), and two species are widespread in Central Europe (Wachmann et al. 2007). They feed on the plants which are covered with glandular hairs and they suck not only plant tissues, but also drops secreted by the glands, and perhaps dead insects which get entangled in the glandular hairs (Wachmann et al. 2007).

The genus Gampsocoris differs from other representatives of the family Berytidae in lacking a frontal process, having a black and shining head and a distinctively long spine on the scutellum. Body is very slender and the individuals always have fully developed wings. Antennae are long, thin, pale with dark rings. Head is rounded, front strongly convex. Pronotum is convex and strongly dotted in its fore part, behind the collar, there are two black, shiny and slightly raised spots (calli); in the back part of the pronotum there are three convex, smooth and black colored nodules, which are equally spaced and characteristically aligned (two on the sides and one in the middle). Scutellum is small, with a characteristic long, protruding and curved downward spine on its basal part. Hemielytra is delicate, almost transparent, veins are well developed. The membrane is large, with a few (5-6) soft longitudinal veins. Scent gland orifices are present. Legs are long, yellowish, with dark rings on femora and tibiae. The total body length varies between 2.5-4.7 mm (Péricart 1984, Lis 2007, Hebda \& Ścibior 2013).

In Poland, the genus Gampsocoris Fuss, 1852 is represented by two species: G. punctipes (Germar, 1822) and G. culicinus Seidenstücker, 1948. Gampsocoris punctipes has the second segment of antennae with distinctive dark rings, and the ventral side of the abdomen pale, with a dark, longitudinal spot in the basal part (Lis 2007). G. punctipes punctipes (Germar, 1822) has tubercles in the posterior part of pronotum which are distinctly darkened and larger than those in G. punctipes pallidus, in which they are pale Péricart (1984). The nominative subspecies is widespread in central and southern Europe and the Mediterranean basin and at the 
coast of the Black Sea. To the north it reaches to about the 55 latitude. G. punctipes pallidus occurs in Asia Minor (Péricart 1984).

Gampsocoris culicinus differs distinctly from G. punctipes in coloration of antennal segment II, which is pale, and the ventral side of the abdomen, which is uniformly dark brown or black (Lis 2007). It is a southern species, with three known subspecies. G. culicinus culicinus Seidenstücker, 1948 occurs in central and southern Europe, the Mediterranean basin and at the coast of the Black Sea, the Caucasus and Transcaucasia, to Asia Minor. G. culicinus eckerleini Josifov, 1959 is known from the region of the Aegean. G. culicinus melitenus Seidenstücker, 1965 is recorded from the area of the Black Sea basin (Péricart 1984).

In Poland, the nominative subspecies of G. culicinus occurs. So far, it is recorded from one location in the Pieniny Mts. G. culicinus culicinus can be distinguished from the other subspecies by the size of the body (Péricart 1984).

The paper presents the current knowledge on the occurrence of the two species of Gampsocoris in Poland, taking into account new records of both species.

\section{SPECIES CHARACTERISTICS AND THEIR DISTRIBUTION IN POLAND}

\section{Gampsocoris punctipes (Germar, 1822) (Fig. 1.)}

Gampsocoris punctipes is a rather xerophilic species (Péricart 1984). It inhabits mainly warm and dry, open areas (Wachmann et al. 2007), and prefers sandy soils. Imagines and larvae occur close to their host plants. These plants are mainly representatives of the family Fabaceae from the genus Ononis L.: O. spinosa L. and O. repens L., which are indicated as host plants in most parts of the geographic range of this species. In Scotland it is known to feed on $O$. reclinata L., in Ukraine it is reported from O. arvensis L., in Crimea - on O. leiosperma Boiss. Gampsocoris punctipes was also reported on many other plants: in France - Pulmonaria L. (Boraginaceae) and Melissa L. (Lamiaceae) (in Poland also reported on Melissa L. by Strawiński 1956), in Marocco - Phlomis crinita Cav. (Lamiaceae), in Israel Salvia rubifolia L. (Lamiaceae) and Heliotropium L. (Boraginaceae), in Crimea Potentilla taurica Willd. and P. astracanica Jacq. (Rosaceae), Ajuga L. (Lamiaceae) and Melandrium album Garcke (Caryophyllaceae). The species was reported to suck the drops on glandular hairs of plants of the genus Ononis L. These insects also puncture the leaves and stems (Péricart 1984).

Gampsocoris punctipes overwinters as adults, which are active from early spring. Mating takes place in May. Eggs are laid from the end of May or beginning of June until the end of July (by individuals from overwintering generation). Females lay eggs singly on the stems and leaves, and also on glandular hairs. Embryogenesis lasts about a week $\left(20-25^{\circ} \mathrm{C}\right)$. Larvae emerge from the beginning of June. Larval growth takes a few weeks and the first adults of the new generation appear at the beginning of July. It is likely that a second and perhaps a third generation is produced in the same year; development continues to the end of September. From July to August the insects often become very numerous and occur both on the host plants as well as on the neighboring plants. Hibernation takes place from October, in the vicinity of host plants in the soil (Péricart 1984).

Literature data. the Baltic Coast (Pobrzeże Bałtyku): CF55: the Hel Peninsula: 3exx., 07 Jul 2007, ruderal scrub (Lęgowski i Lis 2008), CF34: Gdynia (Smreczyński 1954), XA54: Wielka Wieś, VV67: Wolin Island (Smreczyński 1954); the Pomeranian Lake District (Pojezierze Pomorskie): VV72: Szczecin (Schmidt 1928); the Lubelska Upland (Wyżyna Lubelska): EB69: Ruda Czechowska (Puławy), edge of the forest, 10 Aug 1953 (Strawiński 1963), GB03: near Gródek, meadow habitat, steep slope close to the shrubs, Aug (Strawiński 1959); Lower Silesia (Śląsk Dolny): XS36: Leśnica as Berytus punctipes (Scholtz 1847) and as Metacanthus punctipes (Scholtz 1931); the Roztocze Upland: FA59: Hamernia (on 
Melissa sp.) 17 Aug 1953 (Strawiński 1956); the Western Sudety Mountains (Sudety Zachodnie): XR18: Kłodzko (Smreczyński 1954); the Western Beskidy Mountains (Beskidy Zachodnie): DV39: Niedźwiedź, wet meadow, 18 Aug (Smreczyński 1906, Smreczyński 1910), DV78: Rytro, DV77: Piwniczna, DV87: Łomnica, DV86: Żegiestów, DA00: Maków Podhalański (Smreczyński 1954); the Nowotarska Basin (Kotlina Nowotarska): DV26: Zakopane (Smreczyński 1954); the Eastern Beskidy Mountains (Beskidy Wschodnie): FA11: east of Przemyśl, by the Hołubla brook, 15 Jun, FA10: Spława near Bircza, 07 Jun (Smreczyński 1908) as Metacanthus elegans; the Bieszczady Mountains: FV25: Lutowiska 16 Jun 1975 (Cmoluchowa i Lechowski 1977); the Pieniny Mountains: DV57: Krościenko (Smreczyński 1954); “Galicja” (Nowicki 1864).

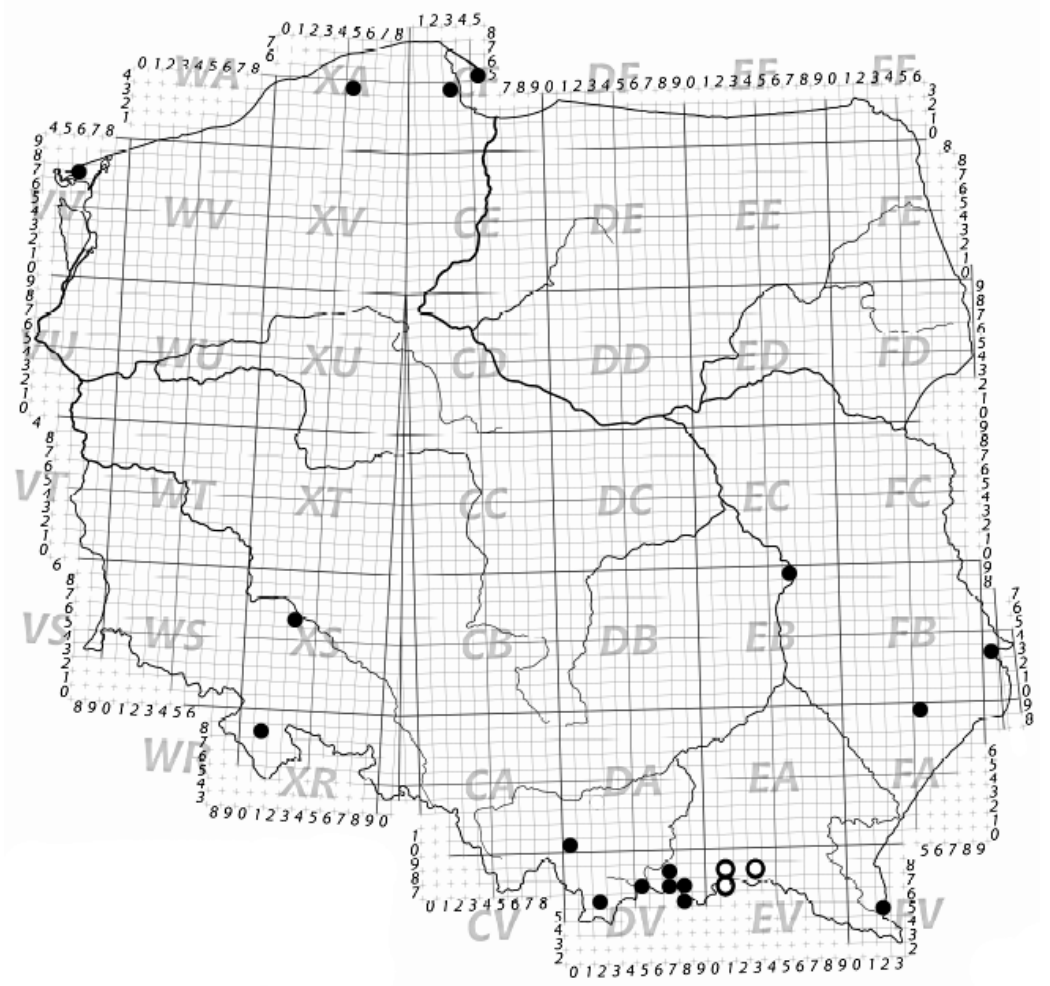

Fig. 1. Distribution of Gampsocoris punctipes (Germ.) in Poland; black dots - literature data, white dots - new data.

New records. the Eastern Beskid Mountains (Beskidy Wschodnie): EV18: Gładyszów, geographical coordinates: 49³0'26"N, 2115'35"E. More than a dozen individuals were captured 25 Aug 2013 using sweep-net. Further searching at this site revealed the presence of an extremely abundant population. The specimens mostly inhabited Ononis L. (a few or more individuals per plant), being also present on neighboring plants. Both, adults and larvae were observed. The habitat comprised the old road crossing the meadow, which was transformed into the shallow ravine by flowing water. The site was relatively well sunlit and warm. EV38: Krempna, geographical coordinates: 49³0'25"N, 2130'4"E. Four individuals were captured 10 Aug 2014 using sweep-net on meadow, on Ononis L. EV17: Blechnarka, geographical coordinates: $49^{\circ} 25^{\prime} 0^{\prime \prime} \mathrm{N}, 21^{\circ} 12^{\prime} 44^{\prime \prime E}$. Two individuals were captured 20 May 2014 in anthropogenic habitat. 


\section{Gampsocoris culicinus Seidenstücker, 1948 (Fig. 2)}

Gampsocoris culicinus is adapted to habitats with various humidity and temperature. Observations indicate that it prefers shady and moist sites, such as the edges of forests and glades. However, reports from Ukraine and France suggest its recognition as a xerophilic species preferring dry and sunny slopes. This species can occur on many species of plants belonging to the families as diverse as: Lamiaceae, Boraginaceae, Scrophulariaceae, Fabaceae, Rosaceae, Caryophyllaceae and Asteraceae, most of which have glandular hairs (Péricart 1984). In Germany most often it has been found on Stachys sylvatica L.

G. culicinus overwinters as an adult form in leaf litter. Copulation takes place in May. Single eggs are laid on the living parts of plants or directly on the ground. Larvae occur from mid-June and can be found until the end of the summer season due to the possibility of occurrence of a second generation. Imagines appear in August (Péricart 1984, Wachmann et al. 2007). It has been reported that G. culicinus may be predator of insects stuck to the glandular hairs of host plants. However, this information requires confirmation (Péricart 1984).

Literaure data. the Pieniny Mountains (Pieniny): DV57 - clearing at the foot of the Three Crowns Peak, dry meadow typical for Pieniny Mts. (Hebda \& Ścibior 2013).

New records. the Eastern Beskid Mountains (Beskidy Wschodnie): EA10: Libusza, geographical coordinates: 49 $40^{\prime} 43^{\prime \prime} \mathrm{N}, 2^{\circ} 15^{\prime} 54^{\prime \prime E}$. A single individual, ô was captured 08 Aug 2013 at the edge of not mowed, overgrowing meadow, using sweep-net.

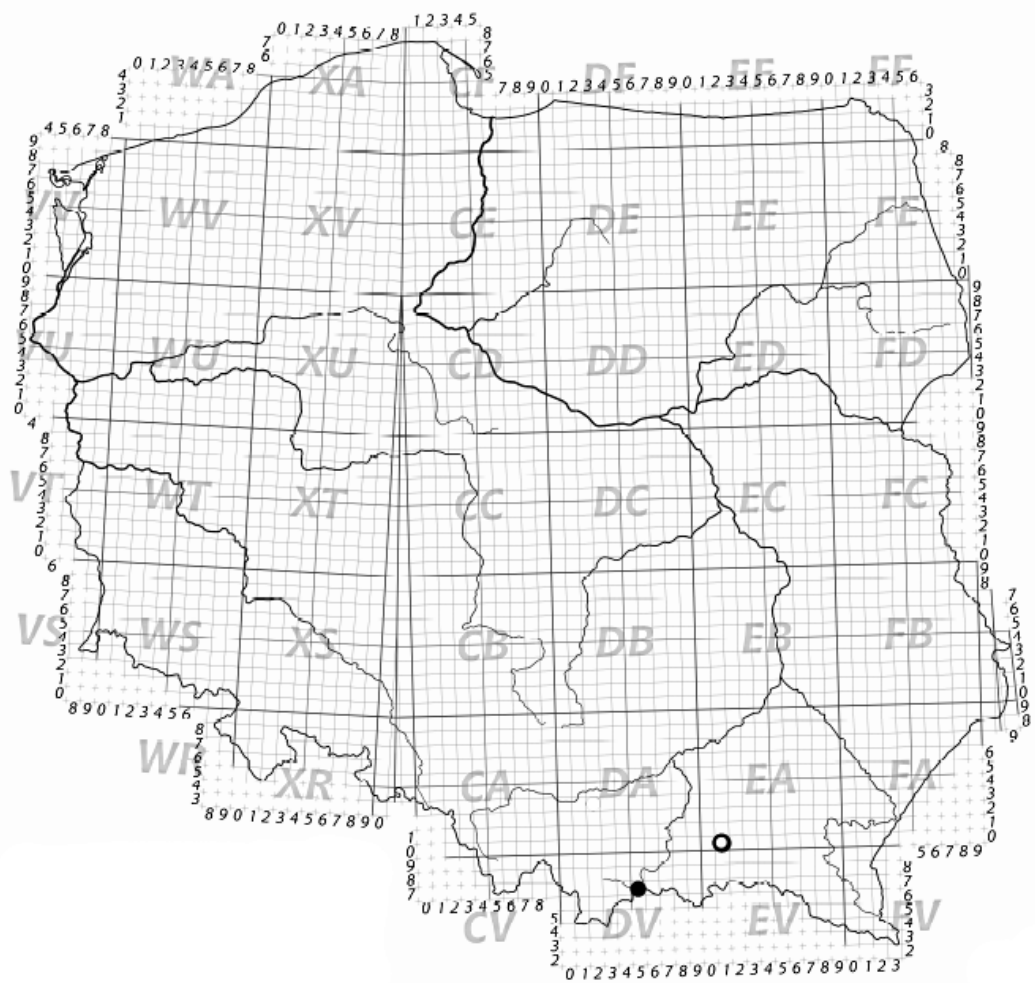

Fig. 2. Distribution of Gampsocoris culicinus Seid. in Poland (black dot - literature record, white dot - new record). 


\section{DISCUSSION}

Specimens of $G$. punctipes were collected so far in the entire country, however, relatively rarely. The occurrence of the main host plant (Ononis L.) probably does not affect its distribution because it is a plant genus common in Poland (Snowarski 2002-2015). The sunlight and thermal conditions seem to be more important factors because this species is considered to be xerophilous (Péricart 1984).

The recent occurrence of $G$. culicinus in the Pieniny Mountains may be associated with an immigration via the Spisz migratory route. During the immigration the habitats that formed on the warm slopes of the valley of the Dunajec River could be used (Mazur 2001). The new records indicate that a second immigration route could be via the Transcarpathian passes in the Low Beskid Mts. This route (Ondavian migration route) is not well documented yet and it is only relevant on a local scale (Mazur 2001). However, in the vicinity of the mountain passes of the Low Beskid Mts. a few species of Heteroptera with the southern type of distribution were collected: on the Dukla Pass - Adelphocoris josifovi Wagner, 1968 (Gorczyca 1992), on the Wysowska Pass - Horistus orientalis (Gmelin, 1790) and Eysarcoris ventralis (Westwood, 1837) (Taszakowski 2012). Similarly, also G. culicinus might be regarded as a xerophilic or thermophilic element in the Polish fauna, as the information about a wide range of habitats relates to warmer areas in the south of Europe. Such observation has been already conducted in case of beetles by Mazur (2001) who claimed, that some species exhibit xerophilic character only on borders of their range, while in its center they remain eurytopic. The new record of this thermophilic species thus reinforce the importance of the Ondavian immigration route of southern species and the formation of the fauna of southern Poland.

\section{REFERENCES}

CMOLUCHOWA A. \& LECHOWSKI L. 1977. Uzupełnienie do poznania pluskwiaków różnoskrzydłych (Heteroptera) Beskidu Wschodniego i Bieszczadów. Annales Universitatis Mariae Curie-Skłodowska, C, 21: 265-270.

GorcZYCA J. 1992. Adelphocoris josifovi Ed. Wagner, 1968 (Heteroptera, Miridae) from Poland. Annales of the Upper Silesian Museum, Entomology, 3: 81-105.

HeBDA G. \& ŚCIBIOR R. 2013. Gampsocoris culicinus Seidenstücker, 1948, species new to the Polish fauna (Heteroptera: Berytidae: Gampsocorinae). Genus 24(1): 29-32.

HENRY T. J. \& FroESCHNER R.C. 1998. Catalog of the stilt bugs, or Berytidae, of the World (Insecta: Hemiptera: Heteroptera). Contributions of the American Entomological Institute, 30: 1-72.

LIS B. 2007. Klucze do oznaczania owadów Polski. Część XVIII. Pluskwiaki różnoskrzydłe - Heteroptera. Zeszyt 9. Płaszczyńcowate - Piesmatidae, smukleńcowate - Berytidae, kowalowate - Pyrrhocoridae. Polskie Towarzystwo Entomologiczne, Toruń. 14-28.

ŁĘGOWSKI D. \& LIS B. 2008. Nowe dane o lądowych pluskwiakach różnoskrzydłych (Hemiptera: Heteroptera) Półwyspu Helskiego (Pobrzeże Bałtyku). Nature Journal (Opole Scientific Society), 41: 117-131.

MAzUR S. 2001. Ryjkowce kserotermiczne Polski: (Coleoptera: Nemonichidae, Attelabidae, Apionidae, Curculionidae). Studium zoogeograficzne. Monografie Fauny Polski 22: 1-378.

NowICKI M. 1864. Przyczynek do owadniczej fauny Galicyi. Rozprawy i Wiadomości Muzeum Dzieduszyckich 1864: $1-87$.

PÉRICART J. 1984. Hémiptères Berytidae euro-méditerranéens - Faune de France 70: 118-137.

PÉRICART J. 2001. Berytidae. In: Aukema B., Rieger C., Catalogue of the Heteroptera of the Palearctic Region: 237-238.

SCHMIDT E. 1928. Verzeichnis der pommerschen Wanzen nach dem Material des Pommerschen Museum für Naturkunde. Abhandlungen und Berichte der Pommerschen Naturforschenden Gesellschaft 9 (3):188-196.

Scholz M. F. R. 1931. Verzeichnis der Wanzen Schlesiens. Entomologischer Anzeiger. Spezialzeitschrift für entomologischen Handel, Verkehr und Literatur, Wien, 11: 79-82, 99-102, 117-120.

SCHOLTz H. 1847. Prodromus zu einer Rhynchoten - Fauna von Schlesien. Übersicht der Arbeiten und Veränderungen der Schlesischen Gesellschaft für Vaterländische Kultur, 1846: 104-164.

SMRECZYŃSKI S. 1906. Wykaz pluskwiaków nowych dla fauny galicyjskiej. Sprawozdanie Komisyi Fizyograficznéj 40: 72-79.

SMRECZYŃSKi S. 1908. Dodatek do spisu pluskiew ś. p. prof. B. Kotuli. Sprawozdanie Komisyi Fizyograficznéj, 43: $1-11$. 
SMRECZYŃSKI S. 1910. Spis pluskwiaków zebranych w Gorcach w roku 1909. Sprawozdanie Komisyi Fizyograficznéj 44: 109-122.

SMRECZYŃSKI S. 1954. Materiały do fauny pluskwiaków (Hemiptera) Polski. Fragmenta. Faunistica 7 (1): 1-146.

SNOWARSKI M. 2002-2015. Atlas roślin naczyniowych Polski; avalaible at www.atlas-roslin.pl.

STRAWIŃSKI K. 1956. Materiały do fauny pluskwiaków (Hem-Heteroptera) Roztocza. Annales Universitatis Mariae Curie-Skłodowska, C, 11 (6): 152-181.

STRAWIŃSKI K. 1959. Badania nad Hemiptera-Heteroptera w projektowanym rezerwacie stepowym koło Gródka, (powiat hrubieszowski). Annales Universitatis Mariae Curie-Skłodowska, C, 11 (1): 1-28.

STRAWIŃSKI K. 1963. Powiązania biocenotyczne owadów Hemiptera-Heteroptera z biotopami zadrzewionymi i niezadrzewionymi w okolicach Puław. Annales Universitatis Mariae Curie-Skłodowska, C, 18 (1): 1-29.

TASZAKOWSKI A. 2012. Lądowe pluskwiaki różnoskrzydłe (Hemiptera: Heteroptera) doliny górnej Ropy. Acta entomologica silesiana 20: 37-54.

Wachmann E., Melber, A. \& Deckert, J. 2007. Pentatomomorpha I. Aradidae, Lygaeidae, Piesmatidae, Berytidae, Pyrrhocoridae, Alydidae, Coreidae, Rhopalidae, Stenocephalidae. Die Tierwelt Deutschlands. 78, Wanzen 3. Goecker, Evers, Keltern: 186-189.

\section{STRESZCZENIE}

\section{[Uwagi na temat występowania Gampsocoris Fuss, 1852 (Hemiptera: Heteroptera: Berytidae) w Polsce]}

Na terenie Polski występują dwa gatunki z rodzaju Gampsocoris Fuss, 1852: Gampsocoris punctipes (Germar, 1822) i Gampsocoris culicinus Seidenstücker, 1948. Oba gatunki związane są głównie z roślinami należącymi do rodzaju Ononis (Fabaceae). W pracy przedstawiono dane literaturowe, a także nowe stanowiska obydwu gatunków stwierdzone w Beskidzie Wschodnim, w tym drugie stwierdzenie G. punctipes na terenie Polski. Zebrano również informacje dotyczące biologii omawianych gatunków i ich powiązania $\mathrm{z}$ roślinami żywicielskimi. Przedstawiono także możliwe drogi wnikania G. culicinus na terytorium Polski. 